\title{
Behavior of subducting sediments beneath an arc under a high geothermal gradient: Constraints from the Miocene SW Japan arc
}

\author{
Gen Shimoda, ${ }^{1,2} *$ YoshiYUKi TATSUMI $^{1,3}$ and YUICHI MoRishitA ${ }^{2}$ \\ ${ }^{1}$ Institute for Geothermal Sciences, Graduate School of Sciences, Kyoto University, Beppu 874-0903, Japan \\ ${ }^{2}$ Geological Survey of Japan, AIST, Central 7, Higashi 1-1-1, Tsukuba 305-8567, Japan \\ ${ }^{3}$ Institute for Frontier Research on Earth Evolution (IFREE), Yokosuka 237-0061, Japan
}

(Received November 7, 2001; Accepted March 31, 2003)

\begin{abstract}
In order to evaluate the role of sediment subduction in the magma genesis in the Setouchi volcanic belt, SW Japan, bulk rock compositions of both pelagic sediments from the Philippine Sea (GDP 15-12) and trench-filled sediments from the Nankai Trough (DSDP site 582) were determined. The analytical result shows that trace element concentrations, particularly $\mathrm{Pb}, \mathrm{Ba}$ and $\mathrm{Th}$, of the pelagic sediments are much higher than those of the terrigenous sediments. Mixing calculations using these elements indicate that the terrigenous sediments rather than the pelagic sediments played a major role in producing the Setouchi magmas. To obtain further constraints on the origin of Setouchi magmas, a model of melt-mantle reaction was examined based on the assimilation fractional crystallization formulation (AFC). The result also indicates that the terrigenous sediment is a dominant metasomatic agent. In addition, the model suggests that the fractionation of orthopyroxene with minor hornblende would be essential to produce the Setouchi magmas. Taking the hornblende fractionation into account, $\mathrm{Pb} / \mathrm{K}_{2} \mathrm{O}$ and $\mathrm{Pb} / \mathrm{Rb}$ ratios on $\mathrm{MgO}$ variation diagrams also indicate similar contributions. Since the breakdown of mica, which is included both in the pelagic and terrigenous sediments, is inferred to induce dehydration melting of the sediments, above geochemical characteristics suggest that both sediments would melt simultaneously beneath the Setouchi area.
\end{abstract}

\section{INTRODUCTION}

Among the slab constituents, sediments have much higher incompatible element concentrations than either altered oceanic crust or mantle peridotite presenting the major incompatible element reservoir of a subducting slab (e.g., McCulloch and Gamble, 1991). As a result, the subducted sediments can have a major effect on the composition of the mantle and modern arc magmas (Armstrong, 1971; Kay et al., 1978; Plank and Langmuir, 1993). Thus models for the origin of the mantle geochemical reservoirs, such as EMI and EMII, require the sediment recycling back into the mantle (Zindler and Hart, 1986; Weaver,
1991).

Due to high mantle temperatures during the early Archean, the production rates of a new continental crust during the period were probably much higher than those during the Phanerozoic period (e.g., McCulloch and Bennet, 1994). Thus, arcs with unusually high geothermal temperature gradients can provide a key constraint on the chemical differentiation of the earth. Although the behavior of an altered oceanic crust in hot subduction zones have been well studied (Defant and Drummond, 1990; Peacock, 1990), the behavior of sediments in hot subduction zone environments have not yet been examined because sediments were presumed to be absent in slabs during the

*Corresponding author (e-mail: h-shimoda@aist.go.jp) 
Archean period.

However, chert, shale and banded iron formations are common in the Archean Greenstone belt (Windley, 1995), indicating that the sediment subduction had already occurred at the Archean time. If this is the case, sediment melting within a slab is also a likely consequence of subduction when steep geothermal temperature gradients are present. In spite of this occurrence, the behavior of sediments in the hot subduction zones has never been considered. While the origin of the first continent, which can provide sediment, is still a puzzle, the effect of sediment subduction to the mantle after the first continental formation should be important to understand the chemical evolution of the earth.

Subducting sediments are composed mainly of terrigenous and pelagic types. Although the relation between subducted sediments and arc magmas has been studied, it is difficult to distinguish the contributions of these types of sediments to the arc magmas because either type of sediment can account for the isotopic compositions, which are commonly used tracer for sediments, of the arc magmas (e.g., Shimoda et al., 1998). Since the contributions of specific sediment sources to arc magmas remain ambiguous, it is important to discriminate the sedimentary signatures in arc magmas by other means in order to understand the cycling of crustal material.

Because of opening of the Japan Sea behind the SW Japan arc and subduction of the young Philippine Sea plate (27-17 Ma; Okino et al., 1994) beneath SW Japan arc in middle Miocene, it has been inferred that unusually high temperature conditions developed beneath that area (Furukawa and Tatsumi, 1999). These high temperatures induced the subducting sediment to melt and produced the Setouchi high-Mg andesites (HMAs) and basalts rather than an altered oceanic crust derived component (Ishikawa and Nakamura, 1994; Shimoda et al., 1998). Although slab melts derived from terrigenous sediments may contribute to the production of Setouchi magmas (Shimoda et al., 1998), the contributions from pelagic sediments have not been considered.

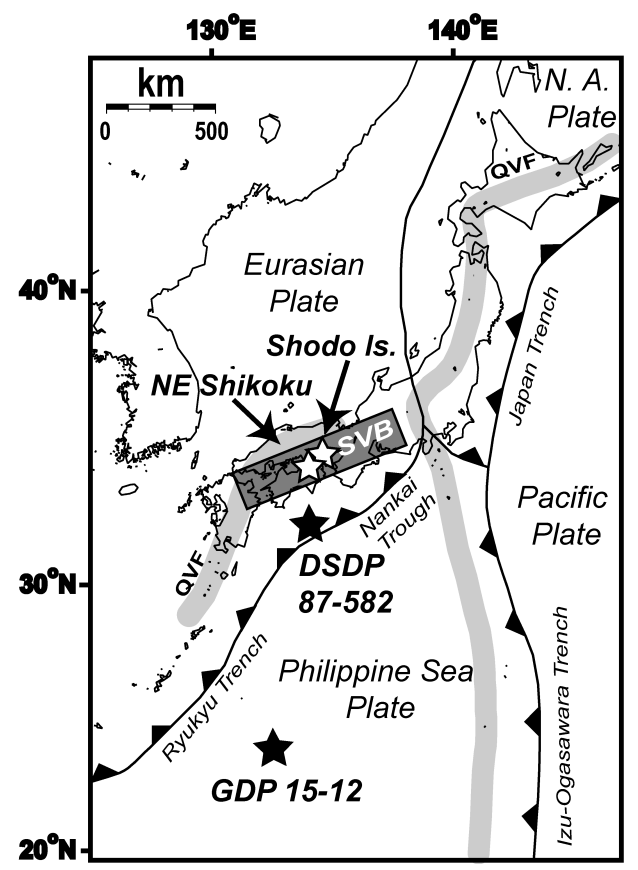

Fig. 1. A locality map of the analyzed sediment samples (solid stars) and the Setouchi volcanic belt (hatched area; SVB). The terrigenous sediments from the Nankai trough and the pelagic sediment from the Philippine Sea were collected by DSDP LEG 582 (Taira and Niitsuma, 1985) and GDP 15-12 (Shiki, 1985), respectively. The Setouchi volcanic belt is shown by the hatched square area (SVB). Stars indicate the locations of NE Shikoku and Shodo-Shima Island. Quaternary volcanic fronts are indicated by heavy gray lines $(Q V F)$.

Although studies based on the chemical composition of sediments are growing in importance, little research work has been conducted using pelagic sediment compositions, probably due to the difficulty in sampling. In this study, the chemical compositions of the pelagic sediments from the Philippine Sea and the terrigenous sediments from the Nankai Trough were determined (Fig. 1). These data revealed the relationship between different types of sediments and the arc magmas at the hot subduction zone, i.e., SW Japan arc. The focus of the study was a detailed analysis and geochemical characterization of pelagic and terrigenous sediments. 

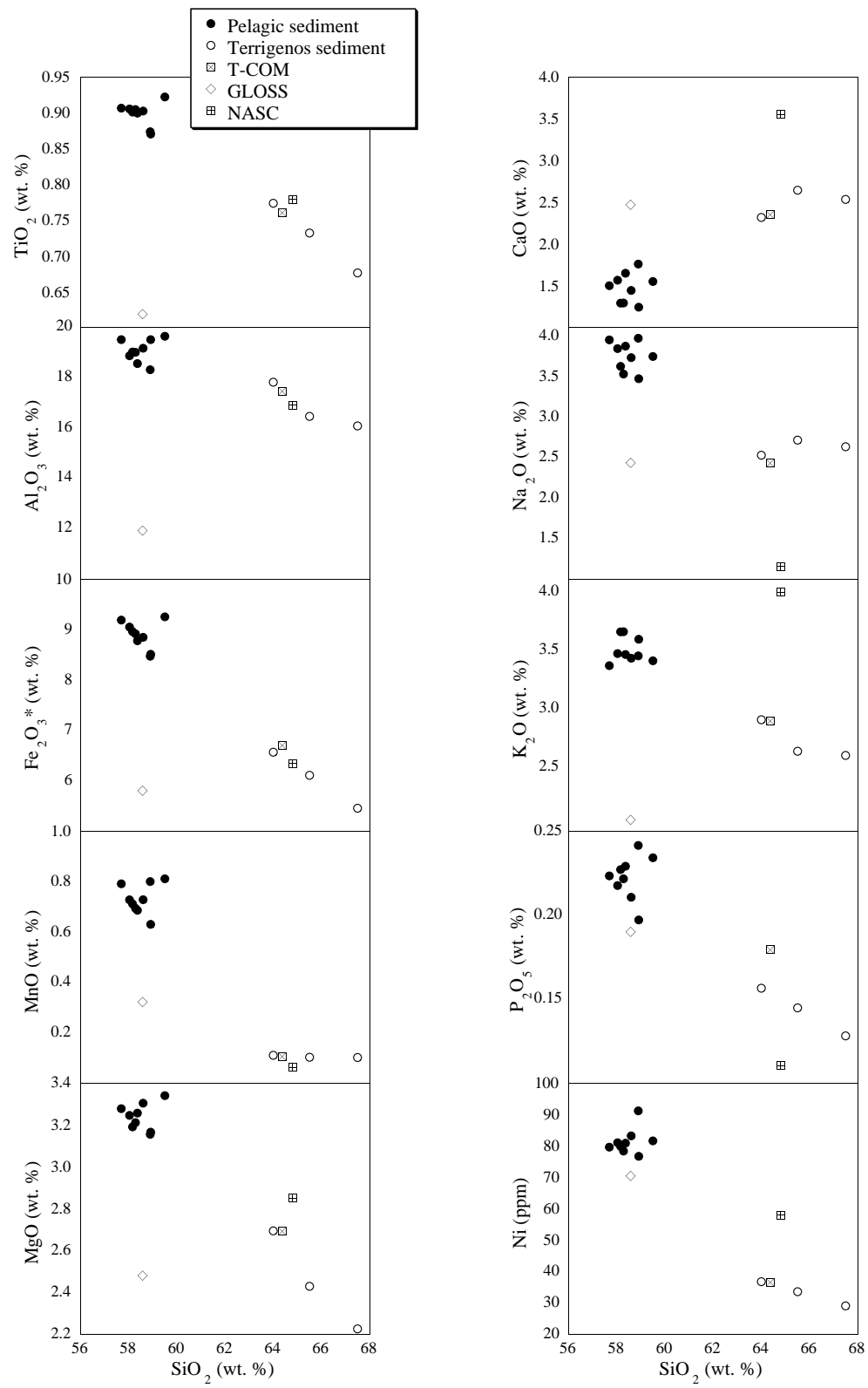

Fig. 2. $\mathrm{SiO}_{2}$ variation diagrams of terrigenous and pelagic sediments. Solid and open circles indicate pelagic and terrigenous sediments, respectively.

\section{SAMPLE DESCRIPTION AND Analytical Procedures}

The Setouchi volcanic belt was selected because the volcanism in this area was related to subduction of young and hot Philippine Sea plate
(27-17 Ma; Kobayashi and Nakada, 1978; Okino et al., 1994) and back arc opening of the Japan Sea (SW Japan rotation; Otofuji et al., 1985, 1991; Jolivet and Tamaki, 1992). The selected pelagic and terrigenous sediments were recovered from the Philippine Sea (GDP 15-12; Fig. 1) and the 


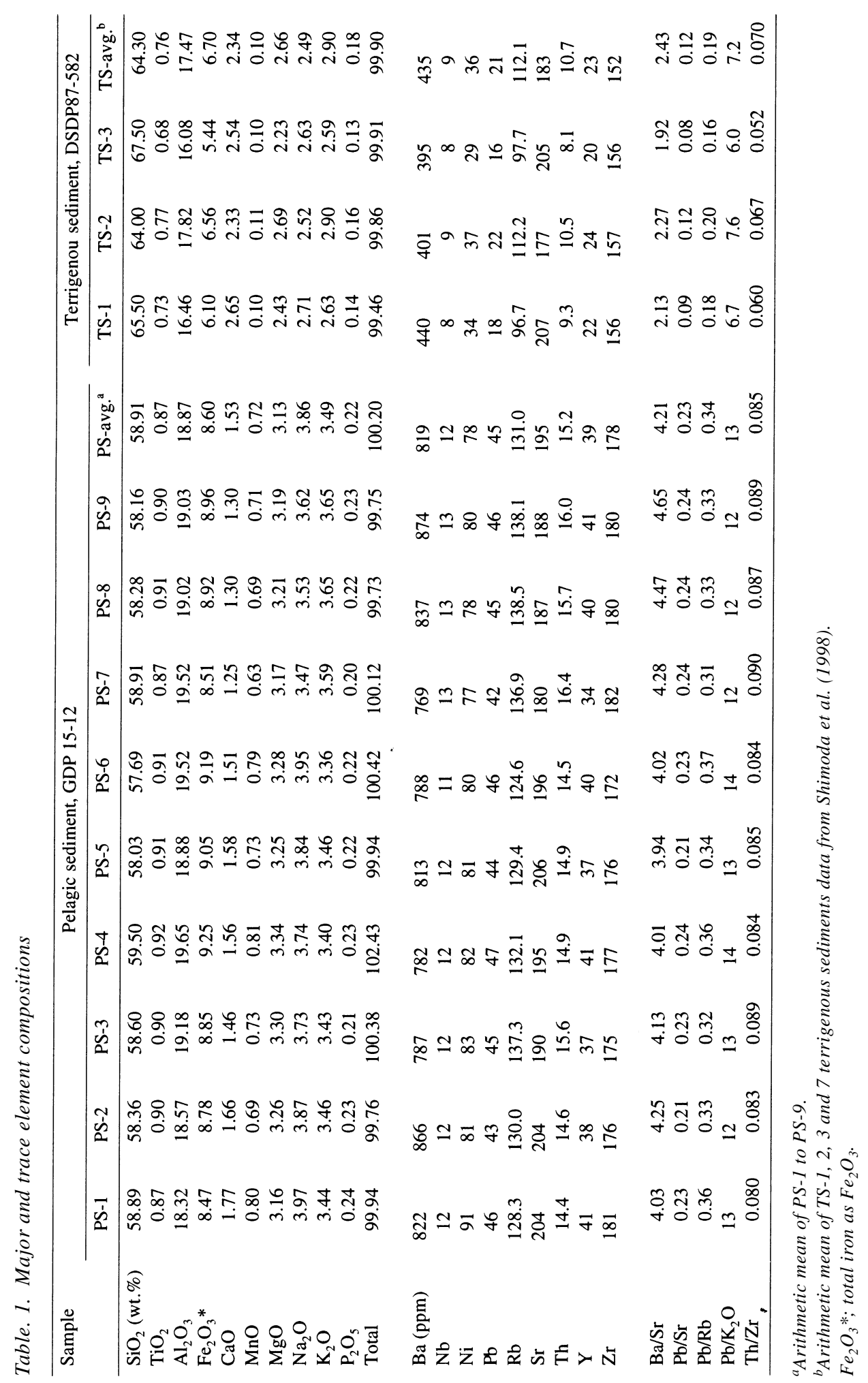


Nankai Trough (Site 582, Leg 87 of the Deep Sea Drilling Program; Fig. 1), respectively, as representative sediments which subducted beneath the SW Japan. Details for these samples have been discussed in Shiki (1985) and Taira and Niitsuma (1985).

For these samples, major and trace elements were analyzed with the RIGAKU ${ }^{\circledR}$ Symaltics 3550 and $3070 \mathrm{X}$-ray fluorescence (XRF) spectrometers using fused glass beads and pressed powder pellets, respectively. Details of counting times, operating conditions and detection limits are in Goto and Tatsumi (1991, 1992). Analytical errors for trace elements are less than 5\%, except for $\mathrm{Pb}$ (7\%). Rare earth elements (REE) concentrations for average pelagic and terrigenous sediment samples were determined with an inductively-coupled plasma atomic emission spectrometer (ICP-AES; Seiko Instruments Inc. SPS 4000) based on the analytical procedure reported by Iwasaki and Haraguchi (1988). These average sediment samples were prepared by even mixtures of pelagic and terrigenous sediments samples, which included sediments reported in Shimoda et al. (1998).

\section{Results}

Major and trace element compositions are listed in Table 1. REE concentrations of composite samples of pelagic and terrigenous sediments are listed in Table 2. The $\mathrm{SiO}_{2}$ variation diagrams and the "spider diagram" for pelagic and terrigenous sediments are shown in Figs. 2 and 3, respectively. Global subducting sediments (GLOSS; Plank and Langmuir, 1998), North American shale composite (NASC; Gromet et al., 1994) and Pacific authigenic weighted mean sediment (PAWMS; Hole et al., 1984) are also shown in these figures as representative sediments.

Figure 2 shows that major element compositions of terrigenous sediments are similar to that of NASC and in good agreement with that of average terrigenous sediments from Nankai Trough (T-COM; Shimoda et al., 1998). This indicates that terrigenous sediment, which used in this study, has
Table. 2. REE compositions

\begin{tabular}{lrrrrr}
\hline & \multicolumn{2}{c}{ PS-C } & & \multicolumn{2}{c}{ TS-C } \\
\cline { 2 - 3 } \cline { 5 - 6 } & ppm & CI norm $^{\mathrm{a}}$ & & ppm & CI norm $^{\mathrm{a}}$ \\
\hline $\mathrm{La}(\mathrm{ppm})$ & 35.9 & 151 & & 22.4 & 95 \\
$\mathrm{Ce}$ & 74.9 & 122 & & 50.3 & 82 \\
$\mathrm{Nd}$ & 33.1 & 71 & & 21.3 & 46 \\
$\mathrm{Sm}$ & 5.9 & 39 & & 4.3 & 28 \\
$\mathrm{Eu}$ & 1.5 & 26 & & 0.9 & 16 \\
$\mathrm{Gd}$ & 6.2 & 30 & & 3.9 & 19 \\
$\mathrm{Dy}$ & 4.9 & 19 & & 3.5 & 14 \\
$\mathrm{Er}$ & 2.4 & 15 & & 1.9 & 11 \\
$\mathrm{Yb}$ & 2.1 & 12 & & 1.8 & 11 \\
\hline
\end{tabular}

${ }^{a}$ CI data from Sun and McDonough (1989).

a common major element composition. Major element compositions of the pelagic sediments in this study, on the other hand, are different from NASC and T-COM.

Trace element patterns of the pelagic and terrigenous sediments, GLOSS, NASC and TCOM are broadly similar (Fig. 3). This trend shows that the pelagic sediments in this study are suitable to infer the behavior of pelagic sediment at the hot subduction zone. In detail, trace elements compositions of the pelagic sediments are characterized by higher trace elements concentrations, especially in $\mathrm{Pb}, \mathrm{Ba}$ and $\mathrm{Th}$ (Fig. 3). Trace elements patterns of the terrigenous sediment are in good agreement with NASC, T-COM and GROSS. To compare the chemical characteristic of subducted sediments and related arc magma, the Setouchi primitive HMAs and basalts are also shown on this figure by the hatched area.

REE patterns of average pelagic and terrigenous sediments are shown in Fig. 4 along with those of GLOSS, NASC and PAWMS. All of these sediments except PAWMS have similar REE patterns. The average pelagic sediment (PS-C) has higher light rare earth elements (LREE) concentration but lower heavy rare earth elements (HREE) concentration than those of GLOSS and NASC, probably reflecting local sedimentation process (Plank and Langmuir, 1998). The average terrigenous sediment (TS-C), on the other hand, has lower REE concentration than GLOSS 


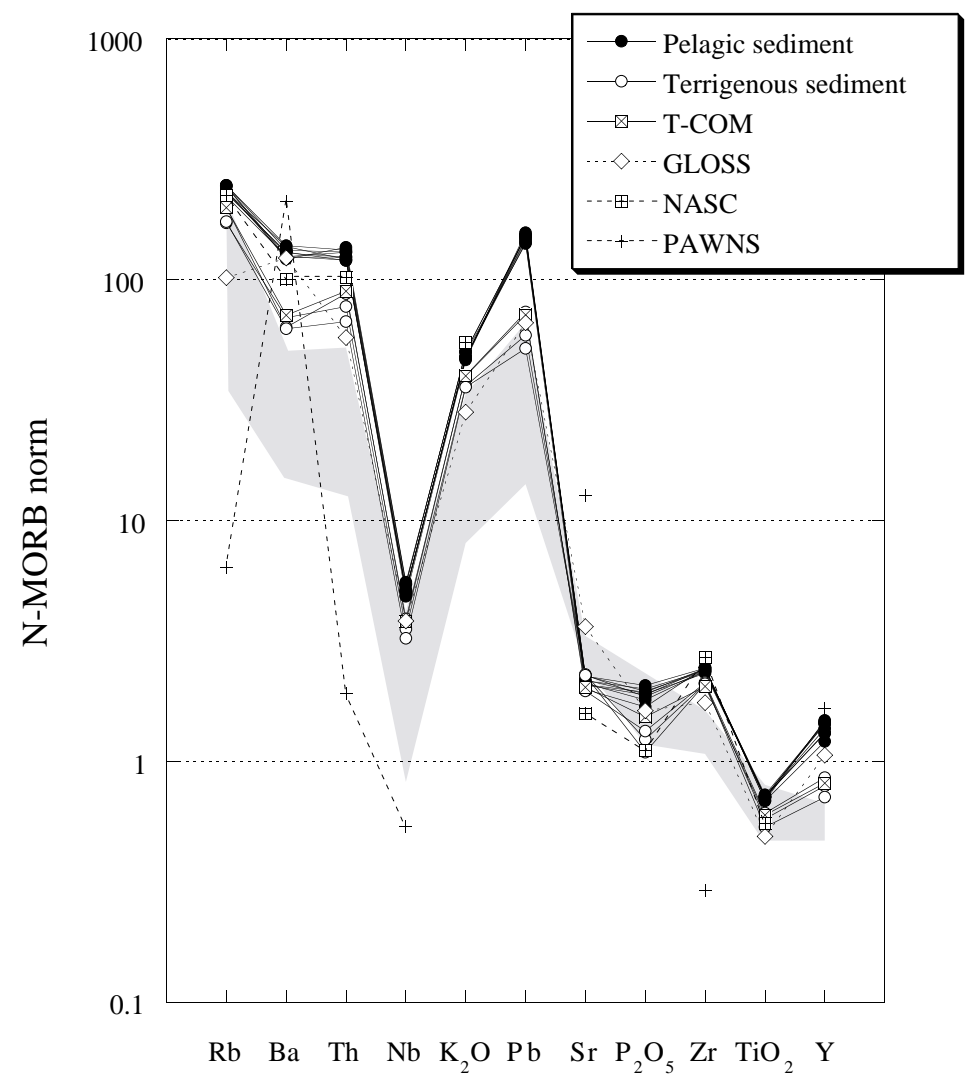

Fig. 3. Spider diagram for pelagic and terrigenous sediments. Trace element compositions of representative sediments, i.e., GLOSS (Plank and Langmuir, 1998), NASC (Gromet et al., 1994) and PAWMS (Hole et al., 1984) are also shown. The Setouchi primitive HMAs and basalts are also shown on this figure by the hatched area.

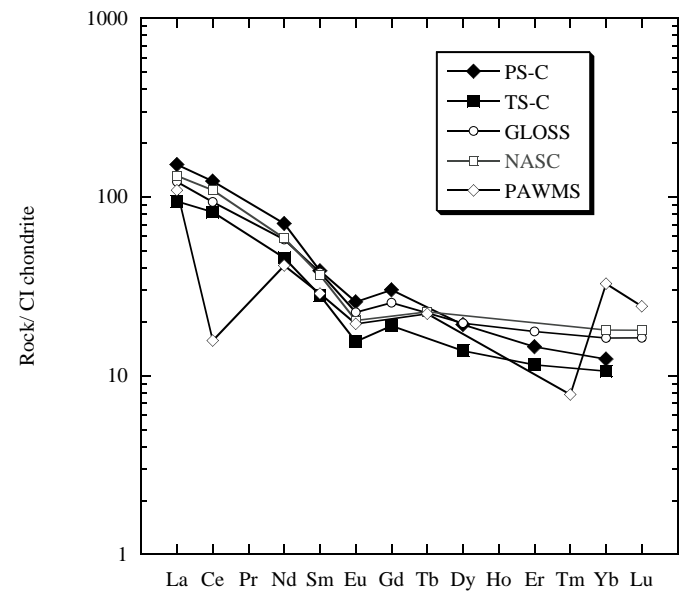

Fig. 4. REE patterns for average pelagic (PS-C) and terrigenous (TS-C) sediments along with those of GLOSS, NASC and PAWMS. and NASC but has similar REE pattern to those of GLOSS and NASC. This REE pattern of TS-C would indicate that the terrigenous sediments in this study are originate from continental detrital materials.

\section{DISCUSSION}

Mixing of mantle peridotite with sediment derived components

Previous studies have demonstrated that the Setouchi magmas are a mixture of mantle peridotite and the melt derived from sediments (e.g., Shimoda et al., 1998). This notion is based on the following reasons: (1) $\mathrm{Pb}, \mathrm{Nd}, \mathrm{Sr}$ and $\mathrm{B}$ isotopic compositions of the Setouchi magmas require the sediment derived component to be a 
metasomatic agent for generation of the Setouchi HMAs and basalts (Ishikawa and Nakamura, 1994; Shimoda et al., 1998); (2) A numerical simulation has demonstrated that a high temperature condition required for sediment melting can be developed beneath the Setouchi area (Furukawa and Tatsumi, 1999); and (3) The Setouchi HMAs and basalt can coexist with mantle peridotite (Tatsumi, 1982). Although the mixing process of the mantle peridotite with the sediment derived melt should be discussed by a reaction proposed by Kelemen (1995) in a strict sense, we will apply the bulk mixing model as the first order approximation to evaluate the processes.

As noted earlier, the relative importance of different types of sediments (i.e., the pelagic vs. terrigenous) in the mixture cannot easily be evaluated because of the similarity in isotopic compositions of commonly utilized geochemical tracers (Shimoda et al., 1998). Here we attempt to apply the trace elemental geochemistry to evaluate individual behaviors of pelagic and terrigenous sediments during the mixing process. In applying the bulk mixing model with elemental compositions, we first need to select the appropriate pairs of elements with similar ionic radius and the same charge. This selection is based on an assumption that the distribution coefficient of elements mainly depends on their ionic radius and charges (Matsui et al., 1977). This would also minimize the effects of possible elemental fractionations during partial melting, fractional crystallization and the other processes, which take place from slab melting through to eruption.

The abundances of $\mathrm{Pb}, \mathrm{Ba}$ and $\mathrm{Th}$ in the pelagic sediments are greatly different from those in the terrigenous sediments (Fig. 3). Thus, these elements should be appropriate to distinguish the contribution of the pelagic and terrigenous sediments in arc magmas. The $\mathrm{Pb}$ and $\mathrm{Ba}$ are divalent elements with ionic radii of 118 and 136 $\mathrm{pm}$, respectively and the $\mathrm{Sr}$ is also divalent with a similar ionic radius of $113 \mathrm{pm}$. Hence, the $\mathrm{Pb}, \mathrm{Ba}$ and $\mathrm{Sr}$ would behave coherently in arc magmas. If this is the case, $\mathrm{Pb} / \mathrm{Sr}$ and $\mathrm{Ba} / \mathrm{Sr}$ ratios can be used as tracers for slab components. In addition to the above two elemental pairs, the ratio of $\mathrm{Th}$ to $\mathrm{Zr}$ might also be used as a tracer of two different sedimentary components because both are tetravalent elements. Before applying these ratios, we discuss the effects of sulfur and zircon on the chemical characteristics of the arc magma, because these would affect the $\mathrm{Pb}$ and $\mathrm{Zr}$ abundances in the magma.

Regarding the effect of sulfur on $\mathrm{Pb}$ abundance, it should be noted that the most important control of sulfur behavior is the redox condition of the system. In the modern subduction zones, a significant part of sulfur supplied from the slab is transported to the surface carried by the arc magma (Ueda and Sakai, 1984), and the arc magmas is inferred to be produced by the dehydration processes of subducted slab and subsequent melting process of the hydrated mantle wedge, suggesting that the arc magmas are initially water saturated (Tatsumi, 1989). Hence we infer the redox condition of the Setouchi magmatic process would not differ significantly from the modern arc magmatic process even in the mantle wedge because the sediment melting considered to be induced by the dehydration of hydrous minerals (Thompson, 1982; Breton and Thompson, 1988; Vielzeuf and Holloway, 1988), which leads to the formation of a water saturated melt. Thus, it is conceivable that sulfur will also be partitioned into the melt rather than into minerals during the sediment melting and the formation of the Setouchi magmas. As a result, the bulk distribution coefficient of $\mathrm{Pb}$ should be lowered and never be increased with the existence of sulfur in the sediment melt because $\mathrm{Pb}$ is an element with a powerful affinity with sulfur. This indicates that the most important characteristic of $\mathrm{Pb}$, i.e., the highly incompatible behavior during the sediment melting, would be preserved.

The chemical fractionation by the zircon saturation is likely consequence in the low temperature siliceous sediment melt (Watson and Harrison, 1983; Johnson and Plank, 1999). In fact, fractionation between $\mathrm{Nb}$ and $\mathrm{Th}$ was observed in Mariana arc lavas which are inferred to be derived from the sediment melt (Elliott et al., 1997). Furthermore, relatively low $\mathrm{Nb}$ and $\mathrm{Zr}$ concentrations 
of the Mariana arc lavas (ca. $1 \mathrm{ppm}$ and $60 \mathrm{ppm}$, respectively; Elliott et al., 1997) provide additional evidence for zircon saturation during the sediment melting. Although the Setouchi HMAs and basalts are considered to be produced by the subducted sediment melting (Shimoda et al., 1998), these magmas are characterized by high $\mathrm{Nb}$ and $\mathrm{Zr}$ concentrations (up to $12 \mathrm{ppm}$ and $120 \mathrm{ppm}$, respectively; Shimoda et al., 1998). This geochemical feature suggests that there is no residual phase which can accommodate HFSE during the sediments melting. Furthermore, less-steep REE patterns of Setouchi HMAs and basalt imply the absence of residual zircon during the sediment melting (Shimoda et al. in prep.). These geochemical characteristics of the Setouchi magmas suggest that HFSE behaved as incompatible elements during sediment melting. It follows that the elemental fractionation between $\mathrm{Zr}$ and $\mathrm{Th}$ would be insignificant during the generation and evolution of the Setouchi magmas.

The difference between the SW Japan and Mariana arcs might be caused by different degrees of partial melting of the subducted sediment due to the different thermal structure. In fact, it has been reported that the degree of partial melting of the subducted sediment beneath the Setouchi area (ca. 50\%; Shimoda and Tatsumi, 1999) are significantly higher than the Mariana area ( $c a .5 \%$; Elliott et al., 1997). The higher degree of partial melting of sediment produced a large amount of melt beneath the Setouchi area and can dissolve zircon in melt to decrease the bulk distribution coefficient to less than unity. Although further study for the effect of zircon saturation during the sediment melting is necessary, it may not affect the HFSE composition of the sediment melt significantly beneath the Setouchi area.

We have shown above that $\mathrm{Pb} / \mathrm{Sr}$ and $\mathrm{Ba} / \mathrm{Sr}$ ratios can be used as possible tracers for the sediment components in Setouchi magmas. In addition to these ratios, $\mathrm{Th} / \mathrm{Zr}$ might be used to infer the source of the Setouchi magmas. Using these elemental ratios, mixing calculations have been conducted based on the following assumptions: (1) Mantle composition is obtained by calculation assuming that an N-type MORB composition (Sun and McDonough, 1989) was produced by equilibrium batch melting (Shaw, 1970) of typical upper mantle peridotite with $10 \%$ partial melting and bulk distribution coefficients estimated by Stolper and Newman (1994); (2) Source mantle composition is changed by a bulk sediment addition with compositions identical to average terrigenous and pelagic sediments compositions; (3) Addition of sediment components to the mantle does not change bulk distribution coefficients; and (4) Contaminated mantle induces equilibrium batch melting with $10 \%$ of partial melting with bulk distribution coefficients estimated by Stolper and Newman (1994).

In these calculations, we assume bulk sediment mixing rather than sediment melt mixing. If the degree of partial melting of sediment is minimal such as beneath the Mariana arc, we should estimate the difference between the bulk sediment mixing and the sediment melt mixing as discussed in Elliott et al. (1997). However, relatively high degree of partial melting of the sediments beneath the Setouchi area (ca. 50\%; Shimoda and Tatsumi, 1999) prevented fractionation among incompatible elements during the sediment melting. Thus the bulk mixing is a reasonable place to start. Although the amount of sediment component in the magma source estimated by the sediment melt mixing is different from that of estimated by the bulk mixing, the paths of mixing curves should be identical in both cases. Since the previous work (Shimoda et al., 1998) estimated the sediment component in magma source by the bulk mixing, we use the bulk mixing to compare the results.

Results of calculations are shown in Fig. 5. These diagrams suggest that the HMAs would be much more contaminated by the sediments than the basalts, indicating the validity of this approach because this trend is consistent with previous studies (e.g., Shimoda et al., 1998). In addition, the contributions of the pelagic and terrigenous sediments to the HMA magma source are calculated to be $\sim 3 \%$ and $\sim 7 \%$, respectively. Although both of mixings (pelagic vs. mantle and terrigenous vs. mantle) can account for the el- 

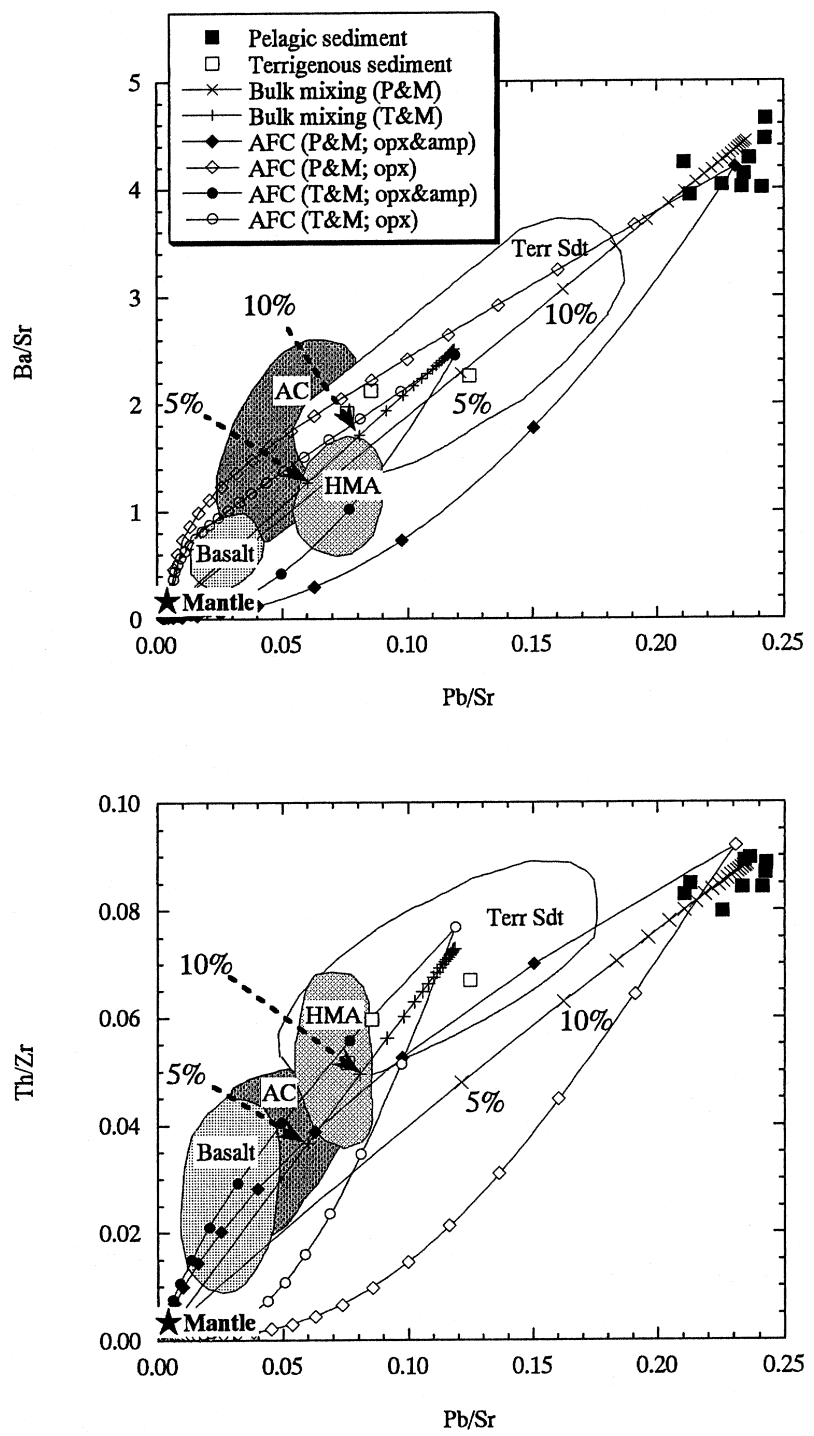

Fig. 5. $\mathrm{Ba} / \mathrm{Sr}$ and $\mathrm{Th} / \mathrm{Zr}$ vs. Pb/Sr diagrams for the pelagic and terrigenous sediments. The compositions of the terrigenous sediment which reported by Shimoda et al. (1998) is shown with an area "Terr Sdt". The areas of the Setouchi HMAs and basalts (Shimoda et al., 1998) are also shown. The ratios of the average continental crust (Rudnick, 1995; Shaw et al., 1986; Wedepohl, 1994; Weaver and Tarney, 1984 and Taylor and McLennan, 1985), is encompassed with an area "AC". $P \& M$ and $T \& M$ indicate the pelagic sediment and the mantle, and the terrigenous sediment and the mantle, respectively. The melt-mantle reaction curves are shown by the AFC. Two cases are assumed for the reaction, namely, fractionation of orthopyroxene and hornblende (opx \& amp) and fractionate of orthopyroxene only (opx). On the reaction curves, symbols are plotted every $5 \%$ decrease of $F$ values.

emental ratios of the Setouchi HMAs, the contributions of the sediments to the HMA magma source would indicate that the terrigenous sediment is a dominant mantle metasomatic compo- nent in the production of the Setouchi HMAs, because isotopic compositions of the HMAs suggest $\sim 10 \%$ contribution of sediment (Shimoda et al., 1998). 
It is important to note that the degree of partial melting and selection of a data set for the bulk distribution coefficients do not affect the result to an appreciable extent because the geochemical characteristics of these elements are similar and thus elemental ratios used in these calculations were relatively constant. Even if the MORB composition used in the calculation is changed to an E-type MORB or OIB (Sun and McDonough, 1989), the contribution of the sediment in the HMA do not change significantly because incompatible element concentrations of the sediment melts are much higher than those of the enriched mantle.

\section{Slab derived melt and mantle interaction}

Since the pioneering work of Kushiro (1969), several experiments both in synthetic and natural systems have shown that HMA can be produced by hydrous melting of peridotite (Tatsumi, 1982; Hirose, 1997; Hirose and Kawamoto, 1995). In addition, a reaction between hydrous $\mathrm{SiO}_{2}$-rich slab melt and overlying mantle peridotite has been proposed as an alternative production mechanism for the HMA (Pearce et al., 1992; Yogodzinski et al., 1994; Kelemen 1995). Although the importance of this reaction is now recognized (e.g., Shimoda et al., 1998), little is known about the behavior of trace elements during the above reactions. Thus it seems worthwhile to examine the effects of the reaction. The following melt-mantle interaction was proposed by Kelemen (1995):

slab melt $\left(\mathrm{SiO}_{2}+\mathrm{H}_{2} \mathrm{O}\right)+$ olivine

$\rightarrow$ orthopyroxene + hornblende + melt .

As this interaction proceeds, the volume of slab derived melt would progressively decrease (Rapp et al., 1999) and composition of the melt becomes more enriched in olivine and more depleted in hornblende and orthopyroxene components. Thus, the above reaction should result in a decrease and increase in $\mathrm{SiO}_{2}$ and $\mathrm{MgO}$ contents, respectively, of the derivative liquids (Carroll and Wyllie, 1989).

An important issue would be how the trace el- ements behave during the melt-mantle reaction. To examine the behavior of the trace elements during the reaction, calculations are conducted with assimilation fractional crystallization formulation (AFC) of Depaolo (1981) based on the following assumptions: (1) Melt compositions of the pelagic and the terrigenous sediments are determined with the method which reported in Tatsumi (2001); (2) An " $r$ " value (the ratio of assimilation and crystallization increment) in the formulation is 0.993 which was inferred from the major element composition of primitive Setouchi HMA (Tatsumi, 2001); (3) Compositional change of the sediment derived melts during the reaction are evaluated with varying " $F$ " value (the residual melt fraction relative to the initial melt amount) from $100 \%$ to $0 \%$; (4) Orthopyroxene is fractionated from the melt with or without minor hornblende (0\% or 10\%); (5) Distribution coefficients are from Rollinson (1993), Green (1994) and LaTourrette et al. (1995) and Chazot et al. (1996).

The results are shown in Fig. 5. The reaction curve of the terrigenous sediment and the mantle well fits the trend of the HMAs, basalts and terrigenous sediments (Fig. 5). It is therefore suggested that the reaction of the terrigenous sediment derived melt with the mantle material is appropriate mechanism to explain the elemental ratios of the Setouchi HMAs and basalts. In addition, these calculations imply that the fractionation of minor hornblende would be essential to produce these trace element compositions of the Setouchi magmas. Assuming that $10 \%$ of hornblende and $90 \%$ orthopyroxene fractionate from the terrigenous sediment derived melt, mass of the HMA and the basalt are calculated to be $c a .95 \%$ and $70 \%$ of the initial melt, respectively. Although it is difficult to judge whether these values are acceptable or not, we believe these values are conceivable. Since the reaction between the pelagic sediment derived melt and the mantle material might also explain the composition of the Setouchi magmas, further consideration should be necessary.

To do so, we paid an attention to the role of 

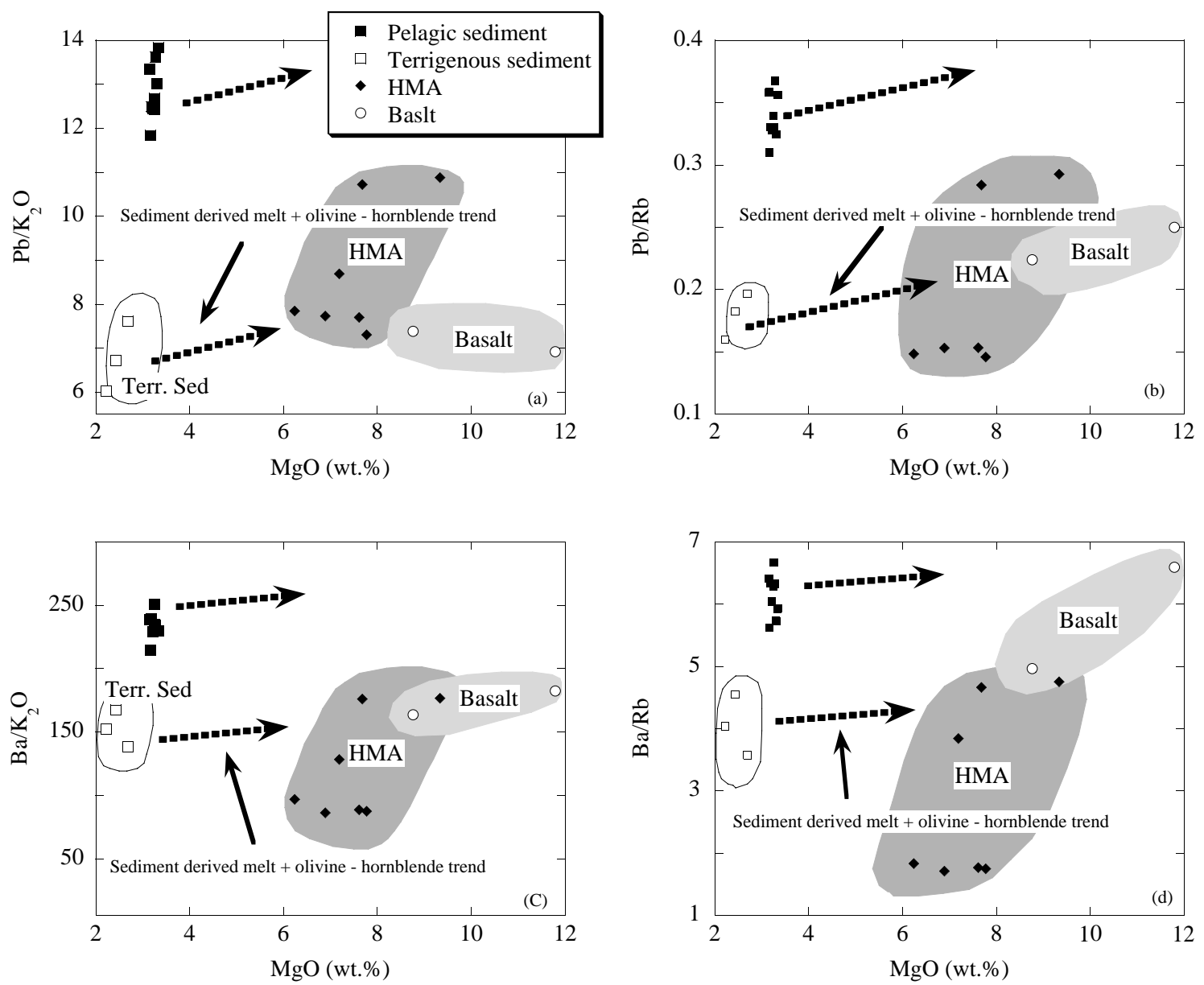

Fig. 6. $\mathrm{MgO}$ variation diagrams for $\mathrm{Pb} / \mathrm{K}_{2} \mathrm{O}, \mathrm{Pb} / \mathrm{Rb}, \mathrm{Ba} / \mathrm{K}_{2} \mathrm{O}$ and $\mathrm{Ba} / \mathrm{Rb}$ ratios for the pelagic and terrigenous sediments together with primitive Setouchi HMA and basalts.

hornblende, because the Setouchi source mantle was inferred to be composed of olivine and pyroxenes without hornblende (Tatsumi, 1982). In addition, we selected LILE rather than HFSE as tracers, because the behavior of LILE is well constrained in comparison to that of HFSE, especially in subduction zone magmatism. Due to relatively large spaces in the hornblende crystal, hornblende can easily accommodate monovalent ions with large ionic radii (ca. 140-150 pm; Papike et al., 1969). Actually, the partition coefficients of K and $\mathrm{Rb}$ between hornblende and melt have been reported to be $0.62-2.2$ and $0.2-1.04$, respectively (Adam et al., 1993; LaTourrette et al., 1995; Dalpé and Baker, 2000), suggesting that hornblende can provide a site for alkaline metal elements. This indicates that $\mathrm{K}$ and $\mathrm{Rb}$ behave weekly incompatible or compatible elements with the hornblende. Other LILE, on the other hand, are highly incompatible with olivine and orthopyroxene and moderately incompatible with hornblende (e.g., Green, 1994). Hence the ratios of LILE over $\mathrm{K}_{2} \mathrm{O}$ and $\mathrm{Rb}$ in the slab-derived melt increase as the reaction proceed.

Another LILE that can provide useful information is $\mathrm{Pb}\left(\mathrm{D}_{\text {hornblend/melt }}=0.04\right.$; LaTourrette $e t$ al., 1995) because its concentrations in pelagic sediments differs from those in terrigenous sediments (Fig. 3). Although Ba is also a member of LILE, it is not suitable to estimate the effect of 
the reaction because it is divalent, but has a 136 pm ionic radius, which is nearly identical to the ionic radius of $\mathrm{K}^{+}$. Indeed, high partition coefficients of $\mathrm{Ba}$ to the hornblende have been reported (0.16-1.59; Adam et al., 1993; LaTourrette et al., 1995; Chazot et al., 1996; Dalpé and Baker, 2000). This indicates that $\mathrm{Ba}$ cannot fractionate from $\mathrm{K}_{2} \mathrm{O}$ and $\mathrm{Rb}$ during the reaction. It should be noted that all of these elements behave as incompatible element during the sediment melting (Vielzeuf and Holloway, 1988; Johnson and Plank, 1999; Tatsumi, 2001), indicating that these elements do not fractionate each other during the sediment melting.

Another measure for the degree of the mantlemelt reaction is the $\mathrm{MgO}$ concentration because the olivine is added to the sediment derived melt during the reaction. Thus, the $\mathrm{MgO}$ concentration of the sediment derived melt correlate with the degree of the interaction. Since the amount of LILE in the mantle olivine is negligible compare to that in the sediment derived melt, $\mathrm{MgO}$ concentration can be independent of the LILE composition of the sediment derived melt. Although the $\mathrm{Mg} /(\mathrm{Mg}+\mathrm{Fe})$ value may be an indicator of this reaction, it might not be suitable to test the reaction because low concentrations of both of these elements in the sediment melt can produce a high $\mathrm{Mg} /(\mathrm{Mg}+\mathrm{Fe})$ value. Thus plots of $\mathrm{MgO}$ concentrations versus $\mathrm{Pb} / \mathrm{K}_{2} \mathrm{O}$ and $\mathrm{Pb} / \mathrm{Rb}$ ratios are used to examine the reaction.

Figure 6 shows the relationships between $\mathrm{MgO}$ concentrations and $\mathrm{Pb} / \mathrm{K}_{2} \mathrm{O}$ and $\mathrm{Pb} / \mathrm{Rb}$ ratios along with primitive $\mathrm{HMAs}$ and basalts $(\mathrm{FeO} * / \mathrm{MgO}$ less than 1; $\mathrm{FeO}^{*}$ total iron as $\mathrm{FeO}$; Shimoda et al., 1998). These diagrams indicate that ratios for the Setouchi HMA and basalts lie between the values for terrigenous and pelagic sediments with higher $\mathrm{Mg}$ concentrations (Figs. 6a and 6b). If the composition of the Setouchi HMA and basalt was determined by the reaction as stated by Shimoda $e t$ al. (1998), it follows that the terrigenous sediment rather than pelagic sediment was the main component in the production of the Setouchi volcanic rocks. Although $\mathrm{Ba}$ is less fractionated from the $\mathrm{K}_{2} \mathrm{O}$ and $\mathrm{Rb}$ as inferred from the ionic radius, the diagrams may be consistent with that the metasomatic agent is derived from the terrigenous sediments (Figs. 6c and 6d).

\section{Behavior of pelagic sediment}

Based on the isotopic study, it has been concluded that unusually high temperatures beneath the Setouchi area induced the subducting sediment to melt and produced the HMA and basalt magmas (Shimoda et al., 1998). In addition, the chemical composition of less fractionated granites, which was produced coincidently on the trench side of the Setouchi volcanic zone, has been explained by the mixing of a primary magma of which composition is similar to the Setouchi HMA with the upper crust (Shinjoe, 1997). These factors suggest that the terrigenous sediments derived melt would also play an important role in the producing arc magma in most of the fore-arc region in the SW Japan arc.

Because of higher concentrations of incompatible elements in the pelagic sediment, it should add a striking effect to the mantle and arc magma compositions, but the pelagic sediments signature was not detected in HMAs and basalts. According to previous works, slab (both of the oceanic crust and sediments) melting was induced by the addition of free $\mathrm{H}_{2} \mathrm{O}$, which is released by the hydrous mineral breakdown (e.g., Defant and Drumond, 1990; Vielzeuf and Holloway, 1988). In the case of the pelitic system, dry solidus (800$870^{\circ} \mathrm{C}$ ) can be defined by mica (muscovite or biotite) dehydration reactions (Thompson, 1982; Breton and Thompson, 1988; Vielzeuf and Holloway, 1988). Hence the pelagic and terrigenous sediments should melt simultaneously beneath the fore-arc region because the mica is a common phase in both sediments.

\section{Implication for the evolution of depleted mantle and continental crust}

Although the pelagic sediments contain a much greater proportion of incompatible elements than the terrigenous sediments, they play a relatively minor role in the production of HMAs and basalts. This observation would reflect the relatively small 
amounts of the pelagic sediment on the slab as observed in present day Nankai trough (Plank and Langmuir, 1998) probably due to the slow deposition rate of pelagic sediments relative to that of terrigenous sediments. In addition, owing to the young age of the Philippine Sea plate, the total accumulation of pelagic sediment was presumably small. Thus pelagic sediments might have melted beneath the Setouchi area without being identifiable.

The common existence of chert and shale in the Archean Greenstone belt (Windley, 1995) would indicate that the sediment was already subducted even in the Archean period. Thus the sediments might also be a major incompatible elements reservoir in the slab during the Archean. Since the sediment can melt at the hot subduction zone, the part of the subducted sediment would be consumed to produce new arc magma in the Archean period. This notion may suggest progressive continental growth. Although there is some uncertainty for the behaviors of HFSE due to refractory minor minerals such as zircon, apatite and rutile, most of LILE, at least, are partitioned into the sediment melt (Johnson and Plank, 1999) and can not subduct into the deeper mantle. Thus, the mantle has never been refertilized in LILE by the sediments subduction at the hot subduction zones. Consequently, the process effectively produced a depleted upper mantle. At the same time, the sediment derived melt which rose through the mantle wedge produced an enriched uppermost mantle such as mantle keel beneath the arcs (proto-continental crust) by the mantle-melt reaction.

\section{Conclusion}

Since the concentrations of $\mathrm{Pb}, \mathrm{Ba}$ and $\mathrm{Th}$ are substantially different in pelagic and terrigenous sediments, these elements can be used to distinguish the sediment types in an arc magma source. In order to reduce the effect of the complicated history of magma generation, $\mathrm{Ba} / \mathrm{Sr}, \mathrm{Th} / \mathrm{Zr}$ and $\mathrm{Pb} /$ $\mathrm{Sr}$ ratios were used to reveal the contribution of the sediments to Setouchi HMA and basalt, which were produced at the subduction zone under unu- sually steep geothermal temperature gradients. The elemental ratios indicate that the terrigenous sediment derived component was the dominant metasomatic agent in the production of the Setouchi HMAs and basalts. Mixing calculations using these ratios are consistent with a recent isotopic study, which has shown that $\sim 10 \%$ of the terrigenous derived material was added to the HMA magma source (Shimoda et al., 1998). Furthermore, the model of the melt-mantle interaction which is based on the assimilation fractional crystallization (AFC) indicates not only that the terrigenous sediment is a dominant metasomatic agent but also that the fractionation of orthopyroxene with minor hornblende $(\sim 10 \%)$ would be essential to produce the Setouchi HMAs and basalts. The $\mathrm{Pb} / \mathrm{K}_{2} \mathrm{O}$ and $\mathrm{Pb} / \mathrm{Rb}$ ratios of the Setouchi HMAs and basalts are higher than those of the terrigenous sediment but lower than those of the pelagic sediment. These trends show that the terrigenous sediment was the main source of the slab-derived component because the reaction between the sediment derived silicic melt and mantle peridotite should raise these ratios. Taking the chemical composition of the pelagic sediment into account, it is possible that the pelagic sediment also melted beneath the Setouchi region, but we cannot detect its signature in either HMAs or basalts. This can be explained by the small amount of the subducted pelagic sediment beneath the SW Japan arc, due to the low sedimentation rate and young age of the slab. The melting of the sediments would preclude incompatible elements, especially LILE, recycling back into the mantle, and may contribute to the progressive continental growth and the evolution of a depleted mantle during the Archean.

Acknowledgments-Terrigenous and Pelagic sediments samples were provided by Prof. A. Taira of The University of Tokyo and Prof. T. Shiki of Kyoto University. We thank Prof. J. P. Matthews, Prof. F. Udo, Prof. K. Uto, Dr. S. Ohsawa, Dr. T. Shibata, Dr. T. Kawamoto, Dr. K. Suzuki, Dr. M. Yoshikawa, Dr. T. Sumii and Dr. T. Matsumoto for useful discussions. We are grateful to Prof. S. Nohda, Kumamoto University for critical comments. We wish to sincerely acknowl- 
edge Dr. Orihashi and Dr. Yogodzinski for their constructive comments on the manuscript.

\section{REFERENCES}

Adam, J., Green, T. H. and Sie, S. H. (1993) Proton microprobe determined partitioning of $\mathrm{Rb}, \mathrm{Sr}, \mathrm{Ba}, \mathrm{Y}$, $\mathrm{Zr}, \mathrm{Nb}$ and $\mathrm{Ta}$ between experimentally produced amphiboles and silicate melts with variable F content. Chem. Geol. 109, 29-49.

Armstrong, R. L. (1971) Isotopic and chemical constraints on models of magma genesis in volcanic arcs.

Earth. Planet. Sci. Lett. 12, 137-142.

Breton, N. L. and Thompson, A. B. (1988) Fluid-absent (dehydration) melting of biotite in metapelites in the early stages of crustal anatexis. Contrib. Mineral. Petrol. 99, 226-237.

Carroll, M. R. and Wyllie, P. J. (1989) Experimental phase relations in the system tonalite-peridotite- $\mathrm{H}_{2} \mathrm{O}$ at $15 \mathrm{~kb}$; implications for assimilation and differentiation processes near the crust-mantle boundary. $J$. Petrol. 30, 1351-1382.

Chazot, G., Menzies, M. A. and Harte, B. (1996) Determination of partition coefficients between apatite, clinopyroxene, amphibole, and melt in natural spinel lherzolites from Yemen: Implications for wet melting of the lithospheric mantle. J. Petrol. 30, 13511382.

Dalpé, C. and Baker, D. R. (2000) Experimental investigation of large-ion-lithophile-element, high-fieldstrength-element- and rare-earth-element-partitioning between calcic amphibole and basaltic melt: the effects of pressure and oxygen fugacity. Contrib. Mineral. Petrol. 140, 233-250.

Defant, M. J. and Drummond, M. S. (1990) Derivation of some modern arc magmas by melting of young subducted lithosphere. Nature 347, 662-665.

DePaolo, D. J. (1981) Trace element and isotopic effects of combined wallrock assimilation and fractional crystallization. Earth. Planet. Sci. Lett. 53, 189-202.

Elliott, T., Plank, T., Zindler, A., White, W. and Bourdon, B. (1997) Element transport from slab to volcanic front at Mariana arc. J. Geophys. Res. 102, 14991-15019.

Furukawa, Y. and Tatsumi, Y. (1999) Melting of subducting slab and production of high-Mg andesite magmas: Unusual magmatism in SW Japan at 13-15 Ma. Geophys. Res. Lett. 26, 2271-2274.

Goto, A. and Tatsumi, Y. (1991) Quantitative analyses of rock samples by X-ray fluorescence spectrography. Rigaku-denki J. 22, 28-44 (in Japanese).

Goto, A. and Tatsumi, Y. (1992) Quantitative analyses of rock samples by X-ray fluorescence spectrogra- phy (II). Rigaku-denki J. 23, 50-69 (in Japanese). Green, T. H. (1994) Experimental studies of trace-elements partitioning applicable to igneous petrogenesis-Sedona 16 years later. Chem. Geol. 117, 1-36.

Gromet, L. P., Dymek, R. F., Haskin, L. A. and Korotev, R. L. (1994) The "North American shale composite": Its compilation, major and trace element characteristics. Geochim. Cosmochim. Acta 48, 2469-2482.

Hirose, K. (1997) Melting experiments on lherzolite KLB-1 under hydrous conditions and generation of high-magnesian andesitic melts. Geology 25, 42-44.

Hirose, K. and Kawamoto, T. (1995) Hydrous partial melting of lherzolite at $1 \mathrm{GPa}$-the effect of $\mathrm{H}_{2} \mathrm{O}$ on the genesis of basaltic magmas. Earth. Planet. Sci. Lett. 133, 463-473.

Hole, M. J., Saunders, A. D., Marriner, G. F. and Tarney, J. T. (1984) subduction of pelagic sediments: implications for the origin of Ce-anomalous basalts from Mariana Islands. J. Geol. Soc. London 141, 453-472.

Ishikawa, T. and Nakamura, E. (1994) Origin of the slab component in arc lavas from across-arc variation of $\mathrm{B}$ and $\mathrm{Pb}$ isotope. Nature 370, 205-208.

Iwasaki, K. and Haraguchi, H. (1988) Determination of rare earth elements in geological samples by inductively-coupled plasma atomic emission spectrometry after oxalate coprecipitation and cationexchange column. Anal. Chim. Acta 208, 163-172.

Johonson, M. C. and Plank, T. (1999) Dehydration and melting experiments constrain the fate of the subducted sediment. Geochemistry Geophysics Geosystems 1, paper number 1999GC000014.

Jolivet, L. and Tamaki, K. (1992) Neogene kinematics in the Japan sea region and volcanic activity of the northeast Japan arc. Proc. ODP Sci. Res. 127/128, 1311-1327.

Kay, R. W., Sun, S.-S. and Lee-Hu, C.-N. (1978) Pb and $\mathrm{Sr}$ isotopes in volcanic rocks from the Aleutian Islands and Pribilof Island, Alaska. Geochim. Cosmochim. Acta 42, 263-273.

Kelemen, P. B. (1995) Genesis of high Mg andesites and the continental crust. Contrib. Mineral. Petrol. 120, 1-19.

Kobayashi, K. and Nakada, M. (1978) Magnetic anomalies and tectonic evolution of the Shikoku intra-arc basin. J. Phys. Earth 26, 391-402.

Kushiro, I. (1969) The system forsterite-diopside-silica with and without water at high pressure. Am. J. Sci. 267-A, 269-294.

LaTourrette, T., Hervig, R. L. and Holloway, J. R. (1995) Trace element partitioning between amphibole, phlogopite, and basanite melt. Earth. Planet. Sci. Lett. 135, 13-30.

Matsui, Y., Onuma, N., Nagasawa, H. and Banno, S. 
(1977) Crystal structure control in trace element partition between crystal and magma. Bull. Soc. Fr. Mineral Cristallogr. 100, 315-324.

McCulloch, M. T. and Bennet, V. C. (1994) Progressive growth of the Earth's continental crust and depleted mantle: geochemical constraints. Geochim. Cosmochim. Acta 58, 4717-4738.

McCulloch, M. T. and Gamble, J. A. (1991) Geochemical and geodynamical constraints on subduction zone magmatism. Earth. Planet. Sci. Lett. 102, 358-374.

Okino, K., Shimakawa, Y. and Nagaoka, S. (1994) Evolution of the Shikoku Basin. J. Geomag. Geoelectr. 46, 463-479.

Otofuji, Y., Matsuda, T. and Nohda, S. (1985) Opening mode of the Japan Sea inferred from paleomagnetism of the Japan arc. Nature 317, 603-604.

Otofuji, Y., Itaya, T. and Matsuda, T. (1991) Rapid rotation of southwest Japan-paleomagnetism and K-Ar age of Miocene volcanic rocks of southwest Japan. Geophys. J. Int. 105, 397-405.

Papike, J. J., Ross, M. and Clark, J. R. (1969) Crystalchemical characterization of clinoamphiboles based on five new structure refinements. Mineral. Soc. Am. Spec. Pap. 2, 117-136.

Peacock, S. M. (1990) Fluid processes in subduction zone. Science 248, 329-337.

Pearce, J. A., Laan, S. R. V. D., Arculus, R. J., Murton, B. J., Ishii, T., Piaate, D. W. and Parkinson, J. J. (1992) Boninite and hartzburgite from leg 125 (Bonin-Mariana forearc): A case study of magma genesis during the initial stages of subduction. Proc. ODP Sci. Res. 125, 623-659.

Plank, T. and Langmuir, C. H. (1993) Tracing traceelements from sediment input to volcanic output at subduction zones. Nature 362, 739-743.

Plank, T. and Langmuir, C. H. (1998) The chemical composition of subducting sediment and its consequences for the crust and mantle. Chem. Geol. 145, 325-394.

Rapp, R. P., Shimizu, N., Norman, M. D. and Applegate, G. S. (1999) Reaction between slab melt and peridotite in the mantle wedge: experimental constraints at 38 Gpa. Chem. Geol. 160, 335-356.

Rollinson, H. (1993) Using Geochemical Data: Evaluation, Presentation, Interpretation. Longman Singapore Publisher (Ltd), Shingapore, 352 pp.

Rudnick, R. L. (1995) Making continental crust. Nature 378, 571-578.

Shaw, D. M., Cramer, J. J., Higgins, M. D. and Truscott, M. G. (1986) Composition of the Canadian Precambrian shield and the continental crust of the Earth. The Nature of the Lower Continental Crust (Dawson, J. B. et al., eds.), 257-282, Geol. Soc.,
London.

Shaw, H. R. (1970) Trace element fractionation during anatexis. Geochim. Cosmochim. Acta 34, 237-243.

Shiki, T. (1985) Geology of the Northern Philippine Sea; Geological Result of the GDP Cruises of Japan. Tokai Univ. Press, Tokyo, 296 pp.

Shimoda, G. and Tatsumi, Y. (1999) Generation of rhyolite magmas by melting of subducting sediments in Shodo-Shima island, Southwest Japan, and its bearing on the origin of high-Mg andesites. Isl. Arc 8, 383-392.

Shimoda, G., Tatsumi, Y., Nohda, S., Ishizaka, K. and Jahn, B. M. (1998) Setouchi high-Mg andesites revisited: geochemical evidence for melting of subducting sediments. Earth. Planet. Sci. Lett. 160, 479-492.

Shimoda, G., Nagai, M. and Morishita, Y. (2003) Rare earth elements compositions of Setouchi high $\mathrm{Mg}$ andesites (HMAs) and basalt; an implication for mantle compositional shift beneath the SW Japan arc during Japan Sea opening (in preparation).

Shinjoe, H. (1997) Origin of the granodiorite in the forearc region of southwest Japan; Melting of the Shimanto accretionary prism. Chem. Geol. 134, 237255.

Stolper, E. and Newman, S. (1994) The role of water in the petrogenesis of Mariana trough magmas. Earth. Planet. Sci. Lett. 121, 293-325.

Sun, S.-S. and McDonough, W. F. (1989) Chemical and isotopic systematics of oceanic basalt: implications for mantle composition and processes. Magmatism in Ocean Bains (Saubders, A. D. and Norry, M. J., eds.), Geol. Soc. Spec. Pub., London 42, 313-345.

Taira, A. and Niitsuma, N. (1985) Turbidite sedimentation in the Nankai trough as interpreted from magnetic fabrics, grain size, and detrital model analyses. Init. Rep. DSDP. LXXXVII, 611-632.

Tatsumi, Y. (1982) Origin of high-magnesian andesites in the Setouchi volcanic belt, southwest Japan, II. Melting phase relations at high pressures. Earth. Planet. Sci. Lett. 60, 305-317.

Tatsumi, Y. (1989) Migration of fluid phases and genesis of basalt magmas in subduction zones. $J$. Geophys. Res. 94, 4697-4707.

Tatsumi, Y. (2001) Geochemical modeling of partial melting of subducting sediments and subsequent mantle-melt interaction: Generation of high-Mg andesites in the Setouchi volcanic belt, southwest Japan. Geology 29, 323-326.

Taylor, S. R. and McLennan, S. M. (1985) The Continental Crust: Its Composition and Evolution. Blackwell Scientific, Boston, Mass, 312 pp.

Thompson, A. B. (1982) Dehydration melting of politic rocks and the generation of $\mathrm{H}_{2} \mathrm{O}$-undersaturated 
granitic liquids. Am. J. Sci. 282, 1567-1595.

Ueda, A. and Sakai, H. (1984) Sulfur isotope study of Quaternary volcanic rocks from the Japanese island arc. Geochim. Cosmochim. Acta 48, 1837-1848.

Vielzeuf, D. and Holloway, J. R. (1988) Experimental determination of the fluid absent melting relations in the pelitic system: Consequences for crustal differentiation. Contrib. Mineral. Petrol. 98, 257-276.

Watson, E. B. and Harrison, T. M. (1983) Zircon saturation revisited: temperature and composition effects in a ariety of crustal magma types. Earth. Planet. Sci. Lett. 64, 295-304.

Weaver, B. L. (1991) Trace element evidence for the origin of ocean-island basalts. Geology 19, 123-126.

Weaver, B. L. and Tarney, J. (1984) Empirical approach to estimating the composition of the continental crust. Nature 310, 575-577.

Wedepohl, K. H. (1994) The composition of the continental crust (abstract). Mineral. Mag. 58, Suppl., 959-960.

Windley, B. F. (1995) The Evolving Continents. 3rd ed., John Wiley \& Sons, 526 pp.

Yogodzinski, H. M., Volynets, O. N., Koloskov, A. V., Seriverstov, N. I. and Matvenkov, V. V. (1994) Magnesian andesites and the subduction component in a strongly calc-alkaline series at Piip volcano, far western Aleusian. J. Petrol. 35, 163-204.

Zindler, A. and Hart, S. (1986) Chemical geodynamics. Annu. Rev. Earth Planet. Sci. 14, 493-571. 